Graduate Institute of

International and Development Studies

Working Paper No: 20/2010

\title{
Chinese Networks and Tariff Evasion
}

\author{
Lorenzo Rotunno \\ Graduate Institute of International and Development Studies \\ Pierre-Louis Vézina \\ Graduate Institute of International and Development Studies
}

\begin{abstract}
In this paper we combine the tariff evasion analysis of Fisman and Wei (2004) with Rauch and Trindade's (2002) study of Chinese trade networks. Chinese networks are known to act as trade catalysts by enforcing contracts and providing market information. As tariff evasion occurs outside the law, market information is scant and formal institutions inexistent, rendering networks the more important. We find robust evidence that Chinese networks, proxied by ethnic Chinese migrant populations, increase tariff evasion, i.e. the tariff semi-elasticity of Chinese missing imports. We suggest the effects takes place through matching of illicitminded traders, identification of corrupt customs agents and enforcement of informal contracts.
\end{abstract}

(C) The Authors.

No part of this paper may be reproduced without the permission of the authors. 


\title{
CHINESE NETWORKS AND TARIFF EVASION
}

\author{
Lorenzo Rotunno and Pierre-Louis Vézina ${ }^{1}$
}

First version: October 2010

\begin{abstract}
In this paper we combine the tariff evasion analysis of Fisman and Wei (2004) with Rauch and Trindade's (2002) study of Chinese trade networks. Chinese networks are known to act as trade catalysts by enforcing contracts and providing market information. As tariff evasion occurs outside the law, market information is scant and formal institutions inexistent, rendering networks the more important. We find robust evidence that Chinese networks, proxied by ethnic Chinese migrant populations, increase tariff evasion, i.e. the tariff semi-elasticity of Chinese missing imports. We suggest the effects takes place through matching of illicit-minded traders, identification of corrupt customs agents and enforcement of informal contracts.
\end{abstract}

Keywords: tariff evasion, China, illicit trade, migrant networks JEL classification: F1, K42

Lorenzo Rotunno

Graduate Institute of International and Development Studies

Richard Wagner 1, 5th Floor

Geneva 1202, Switzerland

lorenzo.rotunno@graduateinstitute.ch

Pierre-Louis Vézina

Graduate Institute of International and Development Studies

Av. de la Paix 11a

Geneva 1202, Switzerland

pierre-louis.vezina@graduateinstitute.ch

\footnotetext{
${ }^{1}$ We thank Richard Baldwin, Nicolas Berman, Marco Fugazza, Marcelo Olarreaga and Ben Shepherd for very helpful
} comments. 
While governments often wish to restrict certain goods from crossing borders, their means and will are often insufficient to discourage business minded traders. Smuggling is thus prevalent and can result in violence, corruption, distorted competition and loss of tariff revenue (see Naim 2005 and Fisman and Wei 2004).

In China smuggling is a severe problem authorities have been trying to tackle for many years. According to the General Administration of Customs, customs and police departments have prosecuted more than 90,000 smuggling cases involving goods worth $\$ 24.2$ billion from 1999 to 2004. But much of it remains undetected. According to the same report, smugglers have become shrewder and that poses new challenges (Xinhua News Agency 2004). This paper aims at shedding more light on the determinants of this underground activity.

Recent research (Fisman and Wei 2004, 2009) used discrepancies in official trade statistics to detect smuggling, asserting that imports or exports missing from one country's reports may have been smuggled, misreported or underinvoiced, as noted by Bhagwati (1964). They found that high tariffs and corrupt environments make smuggling more likely. In this paper we argue that another crucial ingredient for smuggling to occur is international networks. Rauch and Trindade (2002) showed that ethnic Chinese networks, notably through interpersonal relationships known as guanxi, could act as trade catalysts by enforcing contracts and providing market information. As smuggling occurs outside the law, market information is hard to find and trust is all the more important to overcome hold-up problems (see Marcouiller 2000). Overseas Chinese networks should hence increase tariff evasion in Chinese trade.

We test this prediction by combining the analysis of Fisman and Wei (2004) with that of Rauch and Trindade (2002). More precisely, we show that the tariff semi-elasticity of Chinese missing imports, i.e. the log difference of exports reported by exporting countries and imports reported by China, increases significantly in the number of overseas Chinese in the exporting country. This result holds under various specifications, different periods and various indicators of Chinese networks. We also 
find that Chinese networks help tariff evasion in their host countries, and that this effect is highest in corrupt countries.

As some may argue that the gap in trade values is too noisy of a measure to capture smuggling, we show that the results also hold when missing imports are measured in quantities. Moreover, we find that, while tariff evasion is more pronounced in differentiated products (as classified by Rauch 1999), Chinese networks appear more useful in evading tariffs when it is hardest, i.e. for nondifferentiated goods.

To show that our results are not due to luck or an omitted variable bias, we run placebo tests interacting tariff with country characteristics that may be correlated with Chinese immigration, such as GDP, distance to China, and trade with China. We find that contiguity and corruption do increase tariff evasion but that the interaction with Chinese networks is robust, losing significance in only one case out of twelve, probably due to collinearity.

We also estimate our model for four Southeast Asian countries and find some evidence, though less robust, of an Indonesian and a Philippine network, suggesting the results may not be specific to overseas Chinese.

To check whether tariff evasion occurs through misreporting, i.e. the declaration of imports as similar goods with lower tariffs, we follow Fisman and Wei (2004) and include the average tariff on similar goods in our model and also add its interaction with the tariff spread within similar product categories. In partner countries, we find evidence of Chinese networks and corruption increasing misreporting, but only when the tariff spread is of at least 10 percentage points.

In the next section we review the literature. Section 2 presents the theoretical framework. Section 3 describes the data and empirical strategy. Section 4 discusses the results and the last concludes. 


\section{LITERATURE REVIEW}

The idea that discrepancy in trade statistics could be attributed to smuggling dates back to Bhagwati (1964). In theory, what one country reports as imports should be equal to what its partner reports as exports, (or plus cost of freight and insurance (cif) if values are reported, rather than quantities). In practice, this is rarely the case. Smuggling may be one of the reasons. Goods may be undervalued or misreported, often with the complicity of customs officials who may take a bribe rather than impose a barrier, or, they can enter or leave a country circumventing customs altogether, hence appearing only on one side.

Fisman and Wei (2004) looked at the missing trade between Hong Kong and China. They found that an increase in tariff (plus VAT) of one percentage point resulted in a $3 \%$ increase in evasion ${ }^{2}$. They also argued that tariff evasion happened through misreporting in similar categories. For example, frozen chicken breasts are passed as turkeys' to avoid high tariffs (Fisman and Miguel 2008). Javorcik and Narciso (2008) confirmed the tariff evasion result, using data on trade between Germany and 10 Eastern European countries. They also argued that a higher level of product differentiation increases tariff evasion as it increases the difficulty in ascertaining prices and classifications, and hence in detecting misreporting or under-invoicing. Mishra, Subramanian and Topalova (2008) confirmed these tariff evasion results for India and found higher tariff semielasticity of missing imports in those products where enforcement of customs law, proxied by the mode of entry, was laxer. More recently many studies have confirmed the tariff evasion result for various African countries (Arndt \& Van Dunem 2006, Bouet \& Roy 2009, Levin \& Widell 2007), North America (Stoyanov 2009), Brazil (Kume et al. 2010), and for a cross section of 74 countries (Jean \& Mitaritonna 2010).

Yet very little research has gone further to identify the determinants of tariff evasion beyond high tariffs and corruption. Two notable exceptions are Yang (2008), who studied the effect of customs

\footnotetext{
${ }^{2}$ In different specifications of their benchmark regression, the tariff semi-elasticity varies from $2.46 \%$ to $3.57 \%$.
} 
reforms on tariff evasion in the Philippines, and Anson et al. (2006), who examined whether preshipment inspection in Indonesia, the Philippines and Argentina were effective in decreasing tariff evasion. Both pre-shipment inspection schemes and customs reforms had mixed results. Fisman, Moustatersky and Wei (2008) is the only paper that underlined the role of experts' knowledge in facilitating smuggling. They provided evidence that indirect trade through Hong Kong's warehouses, which involves agents specialized in processing and distribution, is also a tariff evasion process.

Another branch of international trade focuses on the role of migrant networks in facilitating trade. Greif (1993) pioneered this field studying how Maghribi trading networks of the $11^{\text {th }}$ century could promote trade by providing community enforcement of sanctions that deter violations of contracts. Similarly, Rauch and Trindade (2002) showed that ethnic Chinese trade networks help to match buyers and sellers in the international marketplace by providing market information and enforcing contracts. Moreover, Dunlevy (2006) found that migrant networks were most important for trade in corrupt environments, where trust is most necessary. These mechanisms should hence also be at work for tariff evasion and might have even stronger impacts.

\section{THEORETICAL FRAMEWORK}

There are at least two reasons why migrant networks should also be at work for illicit trade and might have even stronger impacts than on legal trade. The first is that trade matching in an underground activity is even more complicated. Market information does not flow freely and this makes it difficult to learn about illegal and highly profitable opportunities. Overseas Chinese may know exactly which businessmen are ready to engage in tariff evasion transactions and which varieties are in supply and demand in both China and their host countries. As Kotkin (1992) states, "Chinese entrepreneurs remain, in essence, arbitrageurs, their widespread dispersion a critical means of identifying prime business opportunities" (cited in Rauch and Trindade 2002). Besides 
information about the structure of the market, they may know which customs agents are corrupt, both in China and in their host country, and thus smooth the process of bribery.

Second, the total absence of a legal contract enforcement mechanism makes trust enhancement crucial for traders wishing to evade tariffs. For instance, when tariff evasion takes place through double invoicing, exporters send an "informal" invoice directly to the importers indicating the true value of the shipment, while another "official" invoice that undervalues the goods and accompanies these through customs. Enforcing payment of the "informal" invoice can only be done outside the law, rendering trust the most important. Trust was found to be most important for trade when formal institutions are absent and in corrupt environments (Dunlevy 2006). Chinese networks provide this trust notably through interpersonal relationships known as guanxi formed by members with a common background. Lee (2010) states that, in China, a guanxi based on loyalty "may be crucial in determining business successes or at least in pursuing business opportunities since the rules of law have long been absent for the protection of private property rights and economic interests".

One way to think about the role of networks in tariff evasion is the tariff evasion model of Mishra et al. (2008) who draw from the literature on tax evasion (see Slemrod and Yitzhaki 2000). In their model, an importer faces a cost of evasion that increases in the quality of enforcement and a given increase in tariff has a lower impact on evasion the better the quality of custom enforcement. We can extend their logic by adding in the cost of evasion a probability of getting caught that diminishes with Chinese networks. The idea is that it is less risky to do business with overseas Chinese who are more trustworthy, know which customs agents are corrupt, know how to package the goods to disguise them and how to fill export declarations appropriately, and are hence less likely to "mess up" the trade. Indeed, an OECD report (2009) on modus operandi of foreign bribery through intermediaries explains how, when family, friends and other third persons act as intermediaries, "the principal company knows the identity of the foreign public official who receives 
the bribe”. It can then be shown that a decrease in the probability of getting caught increases the tariff elasticity of evasion.

Another way to look at this is to think of illicit trade as a matching process à la Rauch and Casella (2002). In their model, a successful match is seen as a joint venture between partners in both countries who share profits equally. But some matches are unsuccessful as ex ante information is insufficient for all matches to be profitable. A subset of individuals, i.e. the migrants network, has more information about opportunities abroad and hence benefits from these ties to achieve a higher level of profitability in international trade. We can think of tariff evasion as a process only members of the migrant network know ex ante and which makes trade more profitable. Hence tariff evasion should increase with group ties.

In summary, these theoretical explanations imply Chinese networks play a facilitating role in tariff evasion in trade with China. This occurs through the provision of market information, informal contract enforcement and the smoothing of bribery at borders. The empirical analysis aims at testing this prediction.

\section{DATA AND EMPIRICAL STRATEGY}

We use 2005 trade data from Comtrade to compute, for each HS6 product (about 5000 products) and around 160 trade partners, missing imports as log (1+exports to China declared by exporting countries $)-\log \left(1+\right.$ imports declared by China). We use both values and quantity data ${ }^{3}$. We dropped from our dataset all countries that did not report any exports (and any imports when testing the prediction on the partners' side). A list of remaining countries is in the appendix.

We use applied tariff data from TRAINS (simple averages) ${ }^{4}$, corruption data from the Worldwide Governance Indicators of the World Bank and population data, to calculate Chinese networks as a share of total population, from CEPII. Data on overseas Ethnic Chinese, i.e. foreign born migrants

\footnotetext{
${ }^{3}$ We replace missing trade values and quantities with zeros when one side was reporting. For quantities we use all reported quantities except when reported units do not match.

${ }^{4}$ The applied MFN tariffs and the effectively applied tariffs coincide in the case of China since the country was not part of any trade agreements in 2005 .
} 
from China, Hong Kong, Taiwan and Macau, are from the Global Migrant Origin Database, which extends the UN migrants stock data based on the 2000 round of censuses (i.e., taken between 1995 and 2004; see Parsons et al. (2007) for a detailed description) ${ }^{5}$. Summary statistics are in Table 1.

\section{Table 1}

We use 2005 tariff and trade data for two main reasons. The first is that it maximises data availability. The second is that, as explained by Ahn et al. (2010), by 2005, any Chinese firm that wished to directly trade with foreign partners was free to do so, as WTO accession in 2001 implied a progressive removal of trading license and firm size requirements. This freedom to trade for all businesses should increase the relevance of overseas networks.

It is important to note that missing trade is a noisy measure that captures much more than smuggling activities. Import values include cost-insurance and freight (cif) costs whereas export values are free on board (fob), so the difference in reports also include some trade costs. It may also be noisy because of exchange rates miscalculations, lax custom statisticians and indirect trade confusing reports. Nitsch (2009) discusses in detail the various reasons for discrepancies in bilateral trade statistics. Still, as Fisman (2009) reminds us, while the trade gap cannot be used to quantify smuggling precisely, it is still relevant to identify correlation patterns and uncover the causes of illicit flows. Without a doubt, asymmetric trade policies such as tariffs allow us to observe smuggling in missing trade. This is illustrated in Figure 1. Missing trade is white noise when there are no trade barriers. But when imports restrictions are high, i.e. when their tariff is above the $95^{\text {th }}$ percentile (20\%), missing imports are almost strictly positive, in other words, missing from the importer's reports. In the appendix we provide the values of missing imports by partner country and at the two levels of tariffs. In more than $75 \%$ of the cases, missing import values are greater when tariffs are high.

\section{Figure 1}

\footnotetext{
${ }^{5}$ Where foreign-born data are not available the database uses the foreign nationality criterion.
} 
Before testing our main prediction, we estimate the effect of tariffs on Chinese, as well as four southeast Asian, missing imports, i.e., using the following model $^{6}$ :

$$
\text { missing imports } s_{\mathrm{ik}}=\alpha_{\mathrm{i}}+\beta \text { tariff }_{\mathrm{ik}}+\varepsilon_{\mathrm{ik}}
$$

where $\alpha_{\mathrm{i}}$ is a partner fixed effect and $\mathrm{k}$ is a product (HS6-digit tariff line) indicator. Table 2 summarizes the results. We find that a 10 percentage point increase in tariff increases missing imports by about $32 \%$, which is very close to the $30 \%$ estimated by Fisman and Wei (2004) for trade with Hong Kong. This effect is more than twice as high as in Southeast Asia, where it lies around $13 \%$.

\section{Table 2}

We then estimate the tariff semi-elasticity of Chinese missing imports per partner country, dropping countries with too few observations (less than 70), and plot it against the size of the overseas Chinese community (Figure 2). We find a positive relationship suggesting migrant networks may increase tariff evasion ${ }^{7}$. We investigate this further in the next section.

Figure 2

\section{CHINESE NETWORKS AND ILLICIT TRADE}

To examine the role of migrant networks more carefully we interact the migrant network variable with tariffs and estimate:

$$
\text { missing imports } \text { ik }=\alpha_{\mathrm{i}}+\beta_{1} \text { tariff }_{\mathrm{ik}}+\beta_{2}\left(\operatorname{tariff}_{\mathrm{ik}} * \log \left(1+\text { Chinese }_{\mathrm{i}}\right)\right)+\varepsilon_{\mathrm{ik}}
$$

We also estimate the model using Chinese migrants' share of population instead of the size of the Chinese community. As suggested by Rauch and Trindade (2002), the number of Chinese migrants may indicate the number of potential Chinese connections with the partner country, while the share

\footnotetext{
${ }^{6}$ Besides import tariffs, VAT rates can create incentives to underreport imports. China's VAT rates vary from $13 \%$ to $17 \%$ (besides exemptions). In their paper on tariff evasion in trade between Hong Kong and China, Fisman and Wei (2004) add VAT rates to import tariffs at the HS8-digit level, but they report that their results are unchanged if VAT rates are dropped..

${ }^{7}$ Plotting Chinese migrants as a share of the total partner's population on the horizontal axis does not alter the figure. Furthermore, a similar, though less pronounced, figure is found using quantities instead of values.
} 
of the country's population may proxy the probability of picking a Chinese business partner in the foreign country. Results are in Table 3 . For both values and quantities we find evidence of a positive and significant coefficient on the interaction of Chinese networks and tariffs, which also holds when including partner-industry (HS4) fixed effects (not shown). This confirms our prediction that Chinese networks increase tariff evasion. We also adopted a specification with product and partner fixed effects, controlling for all product and partner level characteristics. The coefficient on the interaction term remains positive and significant, though at the $11 \%$ level for values.

Table 3

Figure 3 summarizes the results of column (1) in Table 3, showing how the effect of tariff on missing imports increases as the ethnic Chinese overseas population increases. In trade with the US, where there is more than 1.5 million Chinese-born, an increase in tariff from $10 \%$ to $20 \%$ would increase the value of missing imports by almost $40 \%$. However, in trade with France, where only about 40,000 Chinese migrants live, the same tariff change would increase evasion by less than $25 \%$.

Figure 3

We also estimate the same regression for four Southeast Asian countries. We find a positive and significant effect of migrant networks on tariff evasion for Indonesia and the Philippines, suggesting the results may not be specific to overseas Chinese (Table 4). But these become insignificant when quantities are used instead of values and when we include partner and product fixed effects (results not shown). This indicates that overseas Chinese may be exceptional and may also contribute to tariff evasion in Southeast Asian countries, where Chinese communities are large and usually involved in business (Rauch and Trindade 2002). We thus run the same regression adding overseas Chinese populations in the Southeast Asian regression. A positive coefficient would suggest that, for example, Indonesia's tariff evasion increases on imports from countries with large Chinese 
communities. As seen in Table 5, this is not the case. We find no indication that international Chinese networks play a role in tariff evasion in any of the four Southeast Asian countries. This could suggest Chinese networks provide market information mostly about Chinese smuggling opportunities. .

Table 4 and 5

A possible concern about our estimation is that the results are just applicable to a specific time period. To check for this possibility, we use the data on overseas Chinese population from Rauch and Trindade (2002) that refers to a period around 1990. Therefore, trade and tariff data are from 1994 (previous years have very little Chinese data) ${ }^{8}$. As reported in Table 6, the main result still holds, as the interaction of tariff and Chinese is significant at the $99 \%$ level, despite the more limited coverage of the Rauch and Trindade (2002) dataset on ethnic Chinese (only data 43 countries could be used in the estimation) $)^{9}$.

Table 6

As overseas Chinese could be capturing other country characteristics or bilateral affinity that could affect tariff evasion in China, we run placebo tests interacting tariff with the logs of GDP, GDP per capita, total bilateral trade, distance, with a measure of corruption and a shared border dummy. The results are in table 7 . Only the interactions with border and corruption show up positive and significant, and that only for quantities. The interaction of tariff with Chinese network loses significance only in two cases out of fourteen, i.e. when trade is included in the missing values regression. This may be because of too high collinearity, as the correlation between the interaction of tariff with trade and the interaction of tariff with Chinese is higher than $95 \%$. But when looking at missing quantities, the coefficient on the interaction of tariff and Chinese networks remains

\footnotetext{
${ }^{8}$ The correlation between the logs of Chinese in circa 1990 and circa 2000 is 0.61 .

${ }^{9} \mathrm{We}$ also run a specification in first-difference, but failed to find a statistically significant correlation between the difference in missing imports and the difference in applied tariff in 2005 and 1994 (after having ensured that both data were classified according to the HS1992 system).
} 
significant. Overall, these tests suggest that the effect of Chinese networks on tariff evasion is not channelled through other partner country characteristics related to trade or development.

\section{Table 7}

\section{Different modes of tariff evasion}

To take our analysis further, we examine whether tariff evasion occurs through misreporting in similar categories or simply through underinvoicing and if Chinese networks have different effects on these practices. As FedEx warns on its website (2010), in China, "customs officials still have wide discretion concerning the category in which an import is placed [and have] the flexibility [...] to "negotiate" duties." Tariff dodgers could be declaring imports under a "wrong" product category with a lower tariff, and this with the consent of corrupt customs officials. As outlined above, Chinese migrants might know how to package the goods to disguise them and how to fill export declarations appropriately to smooth the misreporting process.

We explore this possibility by firstly replicating the tests of Fisman and Wei (2004) who include the average tariff on similar goods (within the same HS4 category) on the right hand side of our benchmark regression model (equation (1)) to capture incentives to misclassify imports ${ }^{10}$. The idea is that the lower the average tariff on similar products; the higher will be the amount of misreported imports, and hence the higher the missing imports. A negative and significant coefficient on the average tariff on similar products would thus provide evidence of tariff evasion through misreporting. As seen in columns (1) and (4) of table 8 and unlike Fisman and Wei (2004), we first do not find any evidence of misreporting as the coefficient on tariffs on similar goods is positive and significant. This is in line with Javorcik and Narciso (2008) who find insignificant coefficients on misreporting. However, misreporting may depend on the tariff spread between similar goods. The lower is the tariff on similar goods and the higher is the tariff dispersion, the higher the

\footnotetext{
${ }^{10}$ In their paper, Fisman and Wei (2004) use a weighted average tariff on similar products, with the export values as weights. Their (implicit) assumption is that exports are reported truthfully. This assumption becomes more problematic in our setting with a cross-section of exporters. We nevertheless ran the misreporting tests also with the weighted average in both values and quantities (results not reported) and find similar results.
} 
incentives for misreporting. To test for this, we interact tariff on similar goods with the spread of tariffs within HS4 categories. For quantities, we find a negative and significant coefficient on this interaction suggesting misreporting may occur but only when the tariff spread is of at least 15 percentage points, which represent few cases ${ }^{11}$. We then investigate whether Chinese networks increase the misreporting results but do not find any such evidence (results not reported).

Table 8

This test cannot however capture all types of misreporting. Misreporting may occur in similar goods at the 6 digit level, or in any type of service. For example, a portion of the true value of chicken imports might be declared as marketing services. We leave these questions to further research as our data does not allow computing average tariffs of similar products within 6-digit categories and does not cover trade in services.

Finally, as both Javorcik and Narciso (2008) and Mishra et al. (2008) argue that a higher level of product differentiation increases tariff evasion due to a greater difficulty in ascertaining product price and hence in detecting false reports, we check if this is also the case for Chinese tariff evasion. We use the Rauch (1999) classification and identify products as non-differentiated when both the liberal and conservative classifications indicate that the product is either traded on organized markets or listed in trade publications. Results in table 9 indicate that, as found by previous research, for both values and quantities, a higher degree of product differentiation increases the tariff semi-elasticity of missing imports, hence tariff evasion. However, product differentiation decreases the role of Chinese networks as the coefficient on the interaction of Chinese networks, tariff and the non-differentiated dummy is positive and significant. This result is robust to the inclusion of product and partner fixed effects. This suggests Chinese networks are all the more necessary when evasion is hardest, i.e. for homogenous commodities.

\footnotetext{
${ }^{11}$ Less than $3 \%$ of the "partner country-HS4" observations have a tariff spread larger than $15 \%$. Following the same logic, we use the tariff deviation from the average tariff on similar products (within the same HS4 category) as a measure of misreporting incentives. In presence of misclassification, high deviation should lead to high missing imports. However, we fail to find any evidence in that direction (the coefficient turns out to be negative and significant or insignificant).
} 
Table 9

\section{Tariff evasion in partner countries}

We now look at tariff evasion in partner countries, verifying whether the results hold when looking at missing imports from China. Anecdotal evidence suggests this might indeed by the case. In a recent New York Times report, Donadio (2010) writes about the Chinese network in Prato, Italy:

With its bureaucracy, protectionist policies and organized crime, Italy is arguably Western Europe's least business-friendly country. Yet in Prato, the Chinese have managed to create an entirely new economy from scratch in a matter of years... But what seems to gall some Italians most is that the Chinese are beating them at their own game - tax evasion and brilliant ways of navigating Italy's notoriously complex bureaucracy — and have created a thriving, if largely underground, new sector.

Here, the missing import variable is the log difference between exports reported by China and imports reported by partner countries. The tariffs are those imposed on Chinese imports in partner countries. We also add corruption to the specification, as it varies across countries and should affect the tariff elasticity of missing imports as it might create a more "smuggling-friendly" environment. Tariff dodgers are more likely to escape legal penalties in corrupt countries where customs officials are more inclined to take the bribe than to enforce the law. Results are in table 10.

Table 10

Again we find evidence, for both values and quantities, that Chinese communities increase tariff evasion on goods that come from China. While their expertise is found to be most useful in the most corrupt countries, it remains so in countries with moderate levels of corruption. This is illustrated in Figure 4, which shows how the effect of tariff on missing imports is highest when corruption is high and when Chinese communities are biggest. The statistical significance of the coefficients can be verified in the lower panel. This result confirms the theoretical prediction on the role of the interaction between network communities and high corruption in lowering the probability of being caught.

Figure 4 
We also carry out misreporting tests and get similar results as the interaction of average tariff on similar goods with the tariff spread is again negative and significant (columns 2 and 5 of table 11). Strong evidence of misreporting emerges for tariff evasion in quantities, as the marginal effect of the average tariff on similar goods is negative for all tariff spreads. What's more, we here find that misreporting might be at its highest not only when the tariff spread is high but also when corruption and Chinese networks are big (last row of table 11), suggesting the latter play a role in tariff evasion through misreporting. This fits well with anecdotal evidence from the Philippines where imports of white rice, which normally require an import license and are subject to a $50 \%$ duty and $12 \%$ VAT, have been misreported as mung beans, zero-rated under the ASEAN Free Trade Agreement (Philippine Daily Inquirer 2010).

Table 11

\section{CONCLUSIONS}

This paper argues that a crucial ingredient for smuggling to occur is the presence of international networks. As tariff evasion occurs outside the law, market information is scant and formal institutions inexistent, rendering networks the more important. Combining the analysis of Fisman and Wei (2004) with that of Rauch and Trindade (2002), we find strong evidence that international Chinese networks, proxied by ethnic Chinese migrant populations, play a role in tariff evasion in Chinese trade. More precisely, we show that the tariff semi-elasticity of Chinese missing imports (and missing imports from China) increases significantly in the number of overseas Chinese in the trade partner. Our baseline estimates suggest that a 10\% increase in 2005 import tariffs by China would have increased tariff evasion by $25 \%$ in countries like France with around 40,000 Chineseborn migrants, while it would have led to a $40 \%$ increase in countries with much larger Chinese communities like the US (about 1.5 million Chinese migrants). We suggest the effects takes place through matching of illicit-minded traders, identification of corrupt customs agents and enforcement of informal contracts. The role of corruption is confirmed by the tariff evasion regression in China's 
trade partners where a combination of high corruption and large Chinese communities maximizes tariff evasion.

While this paper provides evidence of widespread tariff evasion through underinvoicing and sometimes, misreporting in similar goods, tariff evasion can take many other forms, such as transhipment via third countries and misreporting of goods as services, where networks might play even stronger roles. Identifying these practices, as well as disentangling the information and trust channels, makes for promising future research.

\section{References}

[1] Ahn, JaeBin, Khandelwal, Amit Kumar and Wei, Shang-Jin (2010). The Role of Intermediaries in Facilitating Trade. NBER Working Paper 15706.

[2] Anson, Jose \& Olivier Cadot \& Marcelo Olarreaga (2006). Tariff Evasion and Customs Corruption: Does Pre-Shipment Inspection Help?. The B.E. Journal of Economic Analysis \& Policy, Berkeley Electronic Press, vol. 0(1)

[3] Arndt, C. \& Van Dunem, J. (2006). Confronting the Issue of the Elasticity of Customs Evasion in Mozambique: An Empirical Study. GTAP Conference on Global Economic Analysis, Addis Ababa, Ethiopia.

[4] Berger, Helge \& Volker Nitsch (2008). Gotcha! A Profile of Smuggling in International Trade. CESifo Working Paper 2475, Munich.

[5] Bhagwati, Jagdish (1964). On the Underinvoicing of Imports. Bull. Oxford Univ. Inst. Statis. 26: pp. 389-97.

[6] Bouet, Antoine \& Devesh Roy (2009). Trade protection and tax evasion: evidence from Kenya, Mauritius and Nigeria," Working Papers 1, CATT - UPPA - Université de Pau et des Pays de l'Adour. 
[7] Donadio, Rachel (2010). Chinese Remake the 'Made in Italy' Fashion Label. New York Times, September 13.

[8] Dunlevy, James A. (2006). The Influence of Corruption and Language on the Protrade Effect of Immigrants: Evidence from the American States. The Review of Economics and Statistics, MIT Press, vol. 88(1), pages 182-186, July.

[9] FedEx (2010), China country profile.

[10] Fisman, Raymond, J. \& Shang-Jin Wei (2004). Tax Rates and Tax Evasion: Evidence from "Missing Imports" in China. Journal of Political Economy, University of Chicago Press, vol. 112(2), pages 471-500, April

[11] Fisman, Raymond, J., Peter Moustakerski \& Shang-Jin Wei (2008). Outsourcing Tariff Evasion: A New Explanation for Entrepôt Trade. The Review of Economics and Statistics, MIT Press, vol. 90(3), pages 587-592, 03

[12] Fisman, Raymond, J. \& Edward Miguel (2008) Economic Gangsters. Princeton University Press.

[13] Fisman, Raymond J. \& Shang-Jin Wei (2009). The Smuggling of Art, and the Art of Smuggling: Uncovering the Illicit Trade in Cultural Property and Antiques. American Economic Journal: Applied Economics, Vol. 1, No. 3, July

[14] Fisman, Raymond (2009). Measuring Tariff Evasion and Smuggling. NBER Reporter: Research Summary 2009 Number 3

[15] Greif, Avner, 1993. Contract Enforceability and Economic Institutions in Early Trade: the Maghribi Traders' Coalition. American Economic Review, American Economic Association, vol. 83(3), pages 525-48, June.

[16] Javorcik, Beata S. \& Gaia Narciso (2008). Differentiated products and evasion of import tariffs. Journal of International Economics, Elsevier, vol. 76(2), pages 208-222, December. 
[17] Jean, Sébastien \& Cristina Mitaritonna (2010). Determinants and pervasiveness of the evasion of custom duties, mimeo

[18] Kume, Honorio, Guida Piani \& Pedro Miranda (2010). Tarifas De Importação E Evasão Fiscal No Brasil. Discussion Papers 1468, Instituto de Pesquisa Econômica Aplicada - IPEA

[19] Lee, S. Y. (2010). Economics of Guanxi as an Interpersonal Investment Game. Review of Development Economics, 14: 333-342

[20] Levin, Jörgen \& Lars Widell (2007). Tax Evasion in Kenya and Tanzania: Evidence from Missing Imports. Working Papers 2007:8, Örebro University, Swedish Business School.

[21] Marcouiller, Douglas S.J. (2000). Hijacking, Hold-Up, and International Trade. Boston College Working Papers in Economics 477

[22] Mishra, Prachi, Arvind Subramanian \& Petia Topalova (2008). Tariffs, Enforcement, and Customs Evasion: Evidence from India. Journal of Public Economics, Elsevier, vol. 92(1011), pp. 1907-25.

[23] Naim, Moises (2005). Illicit: How Smugglers, Traffickers, and Copycats are Hijacking the Global Economy. Doubleday, October

[24] OECD (2009). Typologies on the role of intermediaries in international business transactions. Final Report, October.

[25] Parsons, R. Christopher, Ronald Skeldon, Terrie L. Walmsley \& L. Alan Winters (2007). Quantifying International Migration: A Database of Bilateral Migrant Stocks. World Bank Policy Research Working Paper 4165. March.

[26] Philippine Daily Inquirer (2010). 2 firms charged with smuggling for misdeclaring rice as mung beans. Manila, 5 August.

[27] Rauch, James E., (1999). Networks versus markets in international trade. Journal of International Economics, Elsevier, vol. 48(1), pages 7-35, June. 
[28] Rauch, James E. \& Vitor Trindade (2002). Ethnic Chinese Networks In International Trade. The Review of Economics and Statistics, MIT Press, vol. 84(1), pages 116-130, February.

[29] Stasavage, D. \& C. Daubrée (1998). Determinants of Customs Fraud and Corruption: Evidence from Two African Countries. OECD Development Centre Working Papers, No. 138.

[30] Slemrod, Joel \& Yitzhaki, Shlomo, (2002). Tax avoidance, evasion, and administration. Handbook of Public Economics, edition 1, volume 3, chapter 22, pages 1423-1470.

[31] Stoyanov, Andrey (2009). Tariff Evasion Under Free Trade Agreement: Empirical Evidence from NAFTA. FREIT Working Paper 139

[32] Xinhua News Agency (2004). China Steps up Efforts to Crack down on Smuggling. October 27.

[33] Yang, Dean (2008). Can Enforcement Backfire? Crime Displacement in the Context of Customs Reform in the Philippines. The Review of Economics and Statistics, MIT Press, vol. 90(1), pages 1-14, November. 
Table 1. Summary statistics

\begin{tabular}{|c|c|c|c|c|c|c|}
\hline Variable & Obs & Mean & Median & Std. Dev. & Min & Max \\
\hline \multicolumn{7}{|c|}{ Chinese missing imports } \\
\hline export_value & 90822 & 4063.568 & 10.425 & 61449.26 & 0 & 8220975 \\
\hline import_value & 90822 & 5394.819 & 44.6685 & 81955.29 & 0 & 9691029 \\
\hline missing_import_value & 90822 & -0.96651 & -0.56361 & 2.392711 & -15.485 & 11.21912 \\
\hline export_quantity & 90404 & 7302144 & 166.5 & $5.10 \mathrm{E}+08$ & 0 & $1.17 \mathrm{E}+11$ \\
\hline import_quantity & 90404 & 9578847 & 2075 & $4.96 \mathrm{E}+08$ & 0 & $1.11 \mathrm{E}+11$ \\
\hline missing_import_qty & 90404 & -2.30187 & -1.33947 & 4.415649 & -23.3962 & 17.03606 \\
\hline China tariff & 90822 & 9.316977 & 8.5 & 6.077339 & 0 & 65 \\
\hline \multicolumn{7}{|c|}{ Partners' missing imports } \\
\hline export_value & 254614 & 2575.408 & 22.3255 & 52404.12 & 0 & 8777217 \\
\hline import_value & 254619 & 3485.119 & 48.661 & 64221.57 & 0 & $1.13 \mathrm{E}+07$ \\
\hline missing_import_value & 254614 & -0.71904 & -0.50501 & 2.133677 & -12.4739 & 11.87726 \\
\hline export_quantity & 248870 & 5638173 & 3795 & $1.55 \mathrm{E}+09$ & 0 & $7.71 \mathrm{E}+11$ \\
\hline import_quantity & 250342 & 3344950 & 7684 & $6.13 \mathrm{E}+08$ & 0 & $3.00 \mathrm{E}+11$ \\
\hline missing_import_qty & 248812 & -1.36066 & -0.59695 & 4.725222 & -26.4271 & 22.99488 \\
\hline Partner tariff & 254619 & 8.731757 & 5 & 10.53337 & 0 & 991.49 \\
\hline \multicolumn{7}{|c|}{ Chinese immigrants and corruption } \\
\hline Chinese & 144 & 48130.26 & 1152 & $2.38 \mathrm{E}+05$ & 0 & $2.27 \mathrm{E}+06$ \\
\hline Chinese share & 141 & 0.004214 & 0.000169 & 0.029146 & 0 & 0.340163 \\
\hline corruption & 141 & -0.13928 & 0.177225 & 0.9881 & -2.52976 & 1.385773 \\
\hline
\end{tabular}

Summary statistics are computed on the datasets that are used for the main estimations. Statistics for Chinese,

Chinese share and corruption are calculated using the dataset with variables for tariff evasion in China.

Table 2. Effect of tariffs on missing import values

\begin{tabular}{llllll}
\hline \hline \multirow{2}{*}{ Tariff } & China & Indonesia & Malaysia & Philippines & Thailand \\
\cline { 2 - 6 } & $.0321^{* * *}$ & $.0137^{* * *}$ & $.0142^{* * *}$ & $.0113^{* * *}$ & $.0129^{* * *}$ \\
& $(.00231)$ & $(.00177)$ & $(.00160)$ & $(.00347)$ & $(.00093)$ \\
\hline Obs & 90822 & 46448 & 59754 & 40041 & 76597 \\
R2 & 0.047 & 0.088 & 0.191 & 0.113 & 0.124 \\
\hline
\end{tabular}

Partner fixed effects (least square dummy varibles - LSDV) regressions. Standard errors clustered at the product level . ${ }^{* *}$ denote statistical significance at the $1 \%$ level. 
Table 3. The role of Chinese networks in tariff evasion in China

\begin{tabular}{|c|c|c|c|c|c|c|c|c|}
\hline & \multicolumn{4}{|c|}{ Missing imports values } & \multicolumn{4}{|c|}{ Missing import quantities } \\
\hline & $(1)$ & $(2)$ & $(3)$ & (4) & $(5)$ & $(6)$ & $(7)$ & $(8)$ \\
\hline Tariff & $\begin{array}{l}.00740 \\
(.0066)\end{array}$ & & $\begin{array}{l}.0454 * * * \\
(.0053)\end{array}$ & & $\begin{array}{l}.000665 \\
(.0159)\end{array}$ & & $\begin{array}{l}.0587 * * * \\
(.0100)\end{array}$ & \\
\hline Tariff $\times$ Chinese & $\begin{array}{l}.00239^{* * *} \\
(.0006)\end{array}$ & $\begin{array}{l}.000951^{\dagger} \\
(.0006)\end{array}$ & & & $\begin{array}{l}.00346^{* * *} \\
(.0013)\end{array}$ & $\begin{array}{l}.00227 * * \\
(.0011)\end{array}$ & & \\
\hline Tariff $\times$ Chinese share & & & $\begin{array}{l}.00183 * * * \\
(.0007)\end{array}$ & $\begin{array}{l}.000879 \\
(.0007) \\
\end{array}$ & & & $\begin{array}{l}.00293^{* *} \\
(.0014)\end{array}$ & $\begin{array}{l}.00237 * \\
(.0012)\end{array}$ \\
\hline Obs & 90822 & 90822 & 87022 & 86896 & 90404 & 90285 & 86613 & 86486 \\
\hline $\mathrm{R} 2$ & 0.048 & 0.000 & 0.049 & 0.000 & 0.069 & 0.0001 & 0.072 & 0.0001 \\
\hline Fixed effects & partner & $\begin{array}{l}\text { partner, } \\
\text { product }\end{array}$ & Partner & $\begin{array}{l}\text { partner, } \\
\text { product }\end{array}$ & partner & $\begin{array}{l}\text { partner, } \\
\text { product }\end{array}$ & partner & $\begin{array}{l}\text { partner, } \\
\text { product }\end{array}$ \\
\hline
\end{tabular}

Standard errors clustered at the product level. $* * * * * *$ denote statistical significance at the $1 \%, 5 \%$ and $10 \%$ level. ${ }^{\dagger}$ indicates a $p$-value of 0.106 .

All partner FE regressions are estimated through least square dummy variable (LSDV). Regressions with partner and product fixed-effects are

estimated taking "within" product deviations and adding partner dummies. 
Table 4. Effect of migrant networks on tariff evasion

\begin{tabular}{lccccc}
\hline \multirow{2}{*}{ Tariff } & China & Indonesia & Malaysia & Philippines & Thailand \\
\cline { 2 - 6 } & .00740 & $-.0124 * *$ & $.0147 * * *$ & -.00235 & $.0242 * * *$ \\
Tariff $\times$ migrants & $.00066)$ & $(.00497)$ & $(.00417)$ & $(.00896)$ & $(.00248)$ \\
& $(.0006)$ & $(.000649)$ & $(.000417)$ & $(.000823)$ & $(.000256)$ \\
\hline Obs & 90822 & 46328 & 59746 & 40037 & 76589 \\
R2 & 0.048 & 0.087 & 0.191 & 0.113 & 0.125 \\
\hline
\end{tabular}

Partner fixed effects (LSDV) regressions. Standard errors clustered at the product level. ***, **, * denote statistical significance at the $1 \%, 5 \%$ and $10 \%$ level

Table 5. Effect of migrant and Chinese network on tariff evasion

\begin{tabular}{lccccc}
\hline \hline \multirow{2}{*}{ Tariff } & China & Indonesia & Malaysia & Philippines & Thailand \\
\cline { 2 - 6 } & .00740 & .0132 & $.0146 * * *$ & .00492 & $.0234 * * *$ \\
Tariff $\times$ Chinese & $(.0066)$ & $(.0118)$ & $(.00565)$ & $(.0108)$ & $(.00332)$ \\
& $.00239 * * *$ & $-.00244 * *$ & $2.08 \mathrm{e}-05$ & -.00127 & .000151 \\
Tariff $\times$ migrants & $(.0006)$ & $(.00105)$ & $(.000580)$ & $(.00109)$ & $(.000309)$ \\
& & $.00379 * * *$ & $-7.63 \mathrm{e}-05$ & $.00204 * *$ & $-.00145^{* * *}$ \\
Obs & & $(.00112)$ & $(.000517)$ & $(.001000)$ & $(.000281)$ \\
R2 & 90822 & 46206 & 59741 & 40036 & 76588 \\
\hline Pays & 0.048 & 0.086 & 0.191 & 0.113 & 0.125 \\
\hline
\end{tabular}

Partner fixed effects (LSDV) regressions. Standard errors clustered at the product level. ***, **, * denote statistical significance at the $1 \%, 5 \%$ and $10 \%$ level

Table 6. Effect of Chinese networks on tariff evasion - 1994 vs. 2005

\begin{tabular}{lcc|cc}
\hline \hline & \multicolumn{2}{c|}{ Missing imports values } & \multicolumn{2}{c}{ Missing imports quantities } \\
\cline { 2 - 5 } Tariff & 2005 & 1994 & 2005 & 1994 \\
\cline { 2 - 5 } & .00740 & 0.00315 & .000665 & $-0.0390^{* * *}$ \\
Tariff $\times$ Chinese in 2000 & $(.0066)$ & $(0.0025)$ & $(.0159)$ & $(0.0104)$ \\
& $.00239 * * *$ & & $.00346^{* * *}$ & \\
Tariff $\times$ Chinese in 1990 & $(.0006)$ & $(.0013)$ & $0.00318^{* * *}$ \\
& & & & $(0.0007)$ \\
\hline Obs & & $0.000577 * * *$ & & 47132 \\
R2 & 90822 & 48160 & 90404 & 0.088 \\
\hline Par & 0.048 & 0.044 & 0.069 & \\
\hline
\end{tabular}

Partner fixed effects (LSDV) regressions. Standard errors clustered at the product level. ***, **, * denote statistical significance at the $1 \%, 5 \%$ and $10 \%$ level 
Table 7. The role of GDP, GDPPC, distance, contiguity, corruption and trade in tariff evasion in China

\begin{tabular}{|c|c|c|c|c|c|c|c|c|c|c|c|c|c|c|}
\hline & \multicolumn{7}{|c|}{ Missing imports values } & \multicolumn{7}{|c|}{ Missing import quantities } \\
\hline & $(1)$ & $(2)$ & (3) & (4) & $(5)$ & $(6)$ & (7) & $(8)$ & (9) & $(10)$ & (11) & (12) & $(13)$ & (14) \\
\hline \multirow[t]{2}{*}{ Tariff } & .0314 & .0200 & .0104 & .00786 & .00701 & .00492 & .0143 & $.149 * * *$ & $.0494^{*}$ & .0164 & .00277 & -.000806 & .0318 & .0905 \\
\hline & $(.0284)$ & $(.0140)$ & $(.00887)$ & $(.00668)$ & $(.00658)$ & $(.0096)$ & $(.0381)$ & $(.0512)$ & $(.0262)$ & $(.0186)$ & $(.0159)$ & $(.0158)$ & $(.0229)$ & $(.0660)$ \\
\hline Tariff & $.00245 * * *$ & $.00226^{* * *}$ & $.00233 * * *$ & $.00230 * * *$ & $.00256^{* * *}$ & .00107 & .000175 & $.00490 * * *$ & $.00315^{* *}$ & $.00317 * *$ & $.00309^{* *}$ & $.00407 * * *$ & $.00532 * * *$ & $.00444 * *$ \\
\hline$\times$ Chinese & $(.00079)$ & $(.00065)$ & $(.00062)$ & $(.00062)$ & $(.00060)$ & $(.00104)$ & $(.00112)$ & $(.0016)$ & $(.0014)$ & $(.00132)$ & $(.00132)$ & $(.00130)$ & $(.0019)$ & $(.00209)$ \\
\hline Tariff & -.000897 & & & & & & $-.00418^{* *}$ & $-.0060 * * *$ & & & & & & $-.00637 * *$ \\
\hline$\times$ GDP & $(.0012)$ & & & & & & $(.00181)$ & $(.00204)$ & & & & & & $(.00324)$ \\
\hline Tariff & & -.00111 & & & & & $4.15 \mathrm{e}-05$ & & $-.00453 *$ & & & & & .00104 \\
\hline$\times$ GDPPC & & $(.0014)$ & & & & & $(.00273)$ & & $(.00233)$ & & & & & $(.00475)$ \\
\hline Tariff & & & -.000301 & & & & $.00693 * *$ & & & -.00161 & & & & .00559 \\
\hline$\times$ distance & & & $(.00056)$ & & & & $(.00274)$ & & & $(.00105)$ & & & & $(.00515)$ \\
\hline Tariff & & & & .00441 & & & $.0572 * *$ & & & & $.0200 * *$ & & & .0558 \\
\hline$\times$ border & & & & $(.00504)$ & & & $(.0232)$ & & & & $(.00938)$ & & & $(.0441)$ \\
\hline Tariff & & & & & .00146 & & .00140 & & & & & $.00484^{*}$ & & .00371 \\
\hline$\times$ corruption & & & & & $(.00166)$ & & $(.00313)$ & & & & & $(.00287)$ & & $(.00550)$ \\
\hline Tariff & & & & & & .00175 & $.00723 * * *$ & & & & & & $-.00503 *$ & .00179 \\
\hline$\times$ trade & & & & & & $(.0015)$ & $(.00240)$ & & & & & & $(.00296)$ & $(.00463)$ \\
\hline Obs. & 86977 & 86977 & 90822 & 90822 & 90802 & 86970 & 86937 & 86568 & 86568 & 90404 & 90404 & 90384 & 86562 & 86529 \\
\hline R2 & 0.049 & 0.049 & 0.048 & 0.048 & 0.048 & 0.049 & 0.049 & 0.072 & 0.071 & 0.069 & 0.069 & 0.069 & 0.072 & 0.071 \\
\hline
\end{tabular}

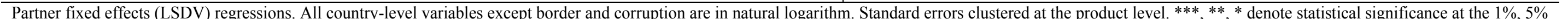
and $10 \%$ levels. 
Table 8. Misreporting tests for tariff evasion in China

\begin{tabular}{lcc|cc}
\hline \hline & \multicolumn{2}{c|}{ Missing import values } & \multicolumn{2}{c}{ Missing import quantities } \\
\cline { 2 - 5 } Tariff & $(1)$ & $(2)$ & $(3)$ & $(4)$ \\
\cline { 2 - 5 } & $.0165^{* * *}$ & $.0143^{* * *}$ & .00769 & -.0105 \\
Avg. tariff on similar goods & $(.0043)$ & $(.0044)$ & $(.0096)$ & $(.0101)$ \\
& $.0218^{* * *}$ & $.0248^{* * *}$ & $.0376^{* * *}$ & $.0670^{* * *}$ \\
HS4 tariff spread & $(.0044)$ & $(.0056)$ & $(.0102)$ & $(.0132)$ \\
& & $.0139^{* *}$ & & $.112^{* * *}$ \\
Avg. tariff on similar goods $\times$ & & $(.0065)$ & & $(.0159)$ \\
HS4 tariff spread & & -.000588 & & $-.00533^{* * *}$ \\
\hline Obs. & & $(.00044)$ & & $(.0011)$ \\
R2 & 75554 & 75554 & 75266 & 75266 \\
\hline Patner fixe & 0.052 & 0.052 & 0.071 & 0.075 \\
\hline
\end{tabular}

Partner fixed effects (LSDV) regressions. Standard errors clustered at the product level. ***, **, * denote statistical significance at the $1 \%, 5 \%$ and $10 \%$ level 
Table 9. Product differentiation and tariff evasion in China

Tariff

Non-differentiated

Tariff $\times$ non-differentiated

Tariff $\times \log$ Chinese

Tariff $\times \log$ Chinese $\times$ non-differentiated

Log Chinese $\times$ non-differentiated

Obs.

R2

Fixed effects

Partner (.00281)

$.00242 * * *$

$(.000271)$

$-3.37 \mathrm{e}-05^{*}$

$(1.84 \mathrm{e}-05)$

import values

(3)

$.0491 * * *$

(.0142)

$.00982 * * *$

$(.00135)$

$-.000468 * * *$

(.000123)

$-.00114$
(.00118)

$3.53 \mathrm{e}-05^{* * *}$

(9.54e-06)

$-.000616^{* * *}$

$(.000105)$

88138

0.052

Partner

Partner FE regressions are estimated through least square dummy variable (LSD) product

$(.000645)$

$3.50 \mathrm{e}-06^{* * *}$

(1.31e-06)

-2.16e-05

(2.11e-05)

88017

000

pressions is either traded on organized markets or listed in trade publications and 0 otherwise.
Missing import quantities

(4) (5) (6)

$\begin{array}{ll}.0436 * * * & .108 * * * \\ (.00608) & (.0224) \\ .0112 * * * & .0301 * *\end{array}$

$.0112 * * * \quad .0301 * * *$

$-.000221 * * * \quad-.00117 * * *$

$(3.36 \mathrm{e}-05) \quad(.000209)$

$-.00531 * * * \quad-.000777$

$(.00186) \quad(.00116)$

$7.86 \mathrm{e}-05^{* * *} \quad 4.20 \mathrm{e}-06^{*}$

(1.61e-05) (2.29e-06)

$-.00158 * * * \quad .000131 * * *$ $(.000212) \quad(3.64 \mathrm{e}-05)$

$.087-001$

$\begin{array}{ccc}.086 & .087 & .001 \\ \text { Partner } & \text { Partner } & \begin{array}{c}\text { Partner an } \\ \text { product }\end{array}\end{array}$


Table 10. The role of Chinese networks in tariff evasion in trading partners

\begin{tabular}{|c|c|c|c|c|c|c|c|c|}
\hline & \multicolumn{4}{|c|}{ "missing import values } & \multicolumn{4}{|c|}{ Missing import quantities } \\
\hline & $(1)$ & $(2)$ & (3) & (4) & $(5)$ & $(6)$ & $(7)$ & $(8)$ \\
\hline \multirow[t]{2}{*}{ Tariff } & -.000779 & & $.0201 * * *$ & & $-.0263 * * *$ & & $.0272 * * *$ & \\
\hline & $(.00209)$ & & $(.00304)$ & & $(.00570)$ & & $(.00628)$ & \\
\hline \multirow[t]{2}{*}{ Tariff $\times$ Chinese } & $.00155^{* * *}$ & $.00141 * * *$ & & & $.00278 * * *$ & $.000706^{* * *}$ & & \\
\hline & $(.000237)$ & $(9.70 \mathrm{e}-05)$ & & & $(.000568)$ & $(.000156)$ & & \\
\hline \multirow[t]{2}{*}{ Tariff $\times$ Chinese share } & & & $.000974 * * *$ & $-.00121 * * *$ & & & $.00377 * * *$ & $-.00059 * * *$ \\
\hline & & & $(.000326)$ & $(.000101)$ & & & $(.000718)$ & $(.000160)$ \\
\hline \multirow[t]{2}{*}{ Tariff $\times$ corruption } & $-.00547 *$ & -.000760 & $.00701 * * *$ & .00110 & $-.0141 * *$ & $-.00827^{*}$ & -.00608 & $-.00824 * *$ \\
\hline & $(.00290)$ & $(.00254)$ & $(.00260)$ & $(.00251)$ & $(.00637)$ & $(.00455)$ & $(.00570)$ & $(.00344)$ \\
\hline Tariff $\times$ corruption $\times$ & $.000897 * * *$ & $.000519 * *$ & & & $.00128 * *$ & .000430 & & \\
\hline Chinese & $(.000267)$ & $(.000251)$ & & & $(.000627)$ & $(.000453)$ & & \\
\hline Tariff $\times$ corruption $\times$ & & & $.000587 * *$ & $3.77 \mathrm{e}-05$ & & & -.000876 & -.000332 \\
\hline Chinese share & & & $(.000299)$ & $(.000342)$ & & & $(.000728)$ & $(.000477)$ \\
\hline Obs. & 252286 & 252185 & 248790 & 248687 & 246661 & 246559 & 243294 & 243190 \\
\hline $\mathrm{R} 2$ & 0.076 & 0.083 & 0.076 & 0.083 & 0.123 & 0.161 & 0.120 & 0.157 \\
\hline Fixed effects & partner & $\begin{array}{l}\text { partner, } \\
\text { product }\end{array}$ & partner & $\begin{array}{l}\text { partner, } \\
\text { product }\end{array}$ & partner & $\begin{array}{l}\text { partner, } \\
\text { product }\end{array}$ & partner & $\begin{array}{l}\text { partner, } \\
\text { product }\end{array}$ \\
\hline
\end{tabular}

through LSDV. Regressions with partner and product fixed-effects are estimated taking "within" product deviations and adding partner dummies. 
Table 11. Misreporting tests à la Fisman and Wei (2004) - partners

\begin{tabular}{|c|c|c|c|c|c|c|}
\hline & \multicolumn{3}{|c|}{ Missing imports values } & \multicolumn{3}{|c|}{ Missing imports quantities } \\
\hline & (1) & $(2)$ & (3) & (4) & $(5)$ & $(6)$ \\
\hline Tariff & $\begin{array}{l}.00718 * * * \\
(.00216)\end{array}$ & $\begin{array}{l}.00588^{* * *} \\
(.00217)\end{array}$ & $\begin{array}{l}.00161 \\
(.00440)\end{array}$ & $\begin{array}{l}.00561 \\
(.00366)\end{array}$ & $\begin{array}{l}-.00119 \\
(.00393)\end{array}$ & $\begin{array}{l}-.0121 \\
(.00996)\end{array}$ \\
\hline Tariff Chinese & & & $\begin{array}{l}.00101 * * \\
(.000490)\end{array}$ & & & $\begin{array}{l}.00186 * \\
(.00105)\end{array}$ \\
\hline Tariff $\times$ corruption & & & $\begin{array}{l}-.00861 \\
(.00564)\end{array}$ & & & $\begin{array}{l}-.0316^{* *} \\
(.0123)\end{array}$ \\
\hline $\begin{array}{l}\text { Tariff } \times \text { Chinese } \times \\
\text { corruption }\end{array}$ & & & $\begin{array}{l}.00129 * * \\
(.000558)\end{array}$ & & & $\begin{array}{l}.00318 * * * \\
(.00119)\end{array}$ \\
\hline Avg tariff on similar goods & $\begin{array}{l}.00579 * * * \\
(.00221)\end{array}$ & $\begin{array}{l}.00746 * * * \\
(.00241)\end{array}$ & $\begin{array}{l}-.00348 \\
(.00465)\end{array}$ & $\begin{array}{l}-.0151 * * * \\
(.00461)\end{array}$ & $\begin{array}{l}-.0128 * * * \\
(.00496)\end{array}$ & $\begin{array}{l}-.0391 * * * \\
(.0112)\end{array}$ \\
\hline HS4 tariff spread & & $\begin{array}{l}.00157 \\
(.00145)\end{array}$ & $\begin{array}{l}-.000415 \\
(.00352)\end{array}$ & & $\begin{array}{l}.0223 * * * \\
(.00320)\end{array}$ & $\begin{array}{l}.0404 * * * \\
(.00805)\end{array}$ \\
\hline $\begin{array}{l}\text { Avg tariff on similar goods } \times \\
\text { Chinese }\end{array}$ & & & $\begin{array}{l}.000918^{*} \\
(.000524)\end{array}$ & & & $\begin{array}{l}.00284 * * \\
(.00115)\end{array}$ \\
\hline $\begin{array}{l}\text { Avg tariff on similar goods } \\
\text { corruption }\end{array}$ & & & $\begin{array}{l}.000443 \\
(.00580)\end{array}$ & & & $\begin{array}{l}.0139 \\
(.0132)\end{array}$ \\
\hline $\begin{array}{l}\text { Avg tariff on similar goods } \times \\
\text { HS4 tariff spread }\end{array}$ & & $\begin{array}{l}-2.20 \mathrm{e}-05 * * \\
(8.74 \mathrm{e}-06)\end{array}$ & $\begin{array}{l}7.66 \mathrm{e}-05 \\
(4.81 \mathrm{e}-05)\end{array}$ & & $\begin{array}{l}-8.13 \mathrm{e}- \\
05 * * * \\
(2.20 \mathrm{e}-05)\end{array}$ & $\begin{array}{l}-7.07 e-05 \\
(9.63 e-05)\end{array}$ \\
\hline HS4 tariff spread $\times$ Chinese & & & $\begin{array}{l}.000198 \\
(.000367)\end{array}$ & & & $\begin{array}{l}-.00175 * * \\
(.000776)\end{array}$ \\
\hline HS4 tariff spread $\times$ corruption & & & $\begin{array}{l}.0118 * * * \\
(.00379)\end{array}$ & & & $\begin{array}{l}.0372 * * * \\
(.00840)\end{array}$ \\
\hline $\begin{array}{l}\text { Avg tariff on similar goods } \times \\
\text { Chinese } \mathrm{x} \text { corruption }\end{array}$ & & & $\begin{array}{l}-.000497 \\
(.000592)\end{array}$ & & & $\begin{array}{l}-.00148 \\
(.00128)\end{array}$ \\
\hline $\begin{array}{l}\text { Avg tariff on similar goods } \times \\
\text { Chinese } x \text { HS } 4 \text { spread }\end{array}$ & & & $\begin{array}{l}-1.31 \mathrm{e}-05^{* * *} \\
(4.74 \mathrm{e}-06)\end{array}$ & & & $\begin{array}{l}-9.48 \mathrm{e}-06 \\
(8.71 \mathrm{e}-06)\end{array}$ \\
\hline $\begin{array}{l}\text { Avg tariff on similar goods } \times \\
\text { corruption } \mathrm{x} \text { HS4 spread }\end{array}$ & & & $\begin{array}{l}-2.77 \mathrm{e}-05 * * \\
(1.29 \mathrm{e}-05)\end{array}$ & & & $\begin{array}{l}-.000104 * * * \\
(2.84 \mathrm{e}-05)\end{array}$ \\
\hline $\begin{array}{l}\text { Avg tariff on similar goods } \times \\
\text { corruption } x \text { HS } 4 \\
\text { spread*Chinese }\end{array}$ & & & $\begin{array}{l}-.00101 * * * \\
(.000371)\end{array}$ & & & $\begin{array}{l}-.00271 * * * \\
(.000778)\end{array}$ \\
\hline Obs. & 225313 & 225313 & 223246 & 220273 & 220273 & 218371 \\
\hline R2 & .077 & .077 & .077 & .120 & .121 & .122 \\
\hline
\end{tabular}


Appendix. China's missing imports (\$ '000)

\begin{tabular}{|c|c|c|}
\hline Partner & tariff $>=20 \%$ & tariff $<20 \%$ \\
\hline Albania & & -4110.734 \\
\hline Algeria & 76.574 & -96195.24 \\
\hline Andorra & & -9.046 \\
\hline Argentina & -2605.849 & -655306.8 \\
\hline Armenia & & -334.638 \\
\hline Australia & -392227.6 & -5748226 \\
\hline Austria & 29582.04 & -238727.6 \\
\hline Azerbaijan & -480.763 & 74469.24 \\
\hline Bahrain & & -39718.72 \\
\hline Bangladesh & -103.872 & -10210.86 \\
\hline Barbados & & -181.111 \\
\hline Belarus & -186.02 & -67108.98 \\
\hline Belgium & -20287.91 & -864737.3 \\
\hline Belize & & -205.036 \\
\hline Benin & -22485.9 & -13015.15 \\
\hline Bhutan & & -1.631 \\
\hline Bolivia & -5.682 & -13497.84 \\
\hline Bosnia \& Herz. & -10.947 & -103250.2 \\
\hline Botswana & -0.212 & -3712.411 \\
\hline Brazil & 20725.7 & -3184573 \\
\hline Bulgaria & -245.177 & -15374.35 \\
\hline Burkina Faso & -163265.7 & -0.741 \\
\hline Burundi & & -327.082 \\
\hline Cameroon & 8027.554 & -10235.72 \\
\hline Canada & -164168 & -1543406 \\
\hline Chile & -4653.809 & -221658.5 \\
\hline Colombia & 629.784 & 30889.94 \\
\hline Cook Islands & & -3699.311 \\
\hline Costa Rica & -49.341 & -12957.66 \\
\hline Cote d'Ivoire & 3226.014 & -8379.759 \\
\hline Croatia & -5.734 & -39183.51 \\
\hline Cuba & -34783.92 & -90459.88 \\
\hline Cyprus & -0.253 & 2988.119 \\
\hline Czech Republic & -266.2538 & -89216.77 \\
\hline Denmark & -4691.322 & -247133 \\
\hline Dominican Rep. & -8.448 & -570.5634 \\
\hline East Timor & & -0.716 \\
\hline Ecuador & -37.026 & -36100.38 \\
\hline El Salvador & -8582.115 & -218.961 \\
\hline Estonia & -426.589 & -24704.75 \\
\hline Ethiopia & -0.106 & -5486.268 \\
\hline Fiji & 64.204 & -689.105 \\
\hline Finland & -15450.04 & -815976.9 \\
\hline France & -36787 & -1687879 \\
\hline French Polynesia & 889.338 & 1512.07 \\
\hline Gabon & 355.83 & -150947.8 \\
\hline Gambia, The & & -170.378 \\
\hline Georgia & -6.18 & 2930.553 \\
\hline Germany & -243015.8 & -5165026 \\
\hline Ghana & -901.375 & -58820.33 \\
\hline Greece & -4471.771 & 6908.388 \\
\hline Greenland & & -28437.32 \\
\hline Guatemala & -32466.36 & -26292.36 \\
\hline Guinea & -1017.198 & -1962.435 \\
\hline
\end{tabular}

\begin{tabular}{|c|c|c|}
\hline Guyana & & -4002.209 \\
\hline Honduras & -1392.711 & -2389.86 \\
\hline Hong Kong, & -284300.5 & -5094703 \\
\hline Hungary & 1492.123 & 15462.4 \\
\hline Iceland & -190.722 & -23780.42 \\
\hline India & 28043.02 & -2748456 \\
\hline Indonesia & -131905.3 & -2522551 \\
\hline Iran & -8621.238 & -5930898 \\
\hline Ireland & 377.934 & -361715.6 \\
\hline Israel & -2536.81 & -448151.8 \\
\hline Italy & 121586.2 & -1183111 \\
\hline Jamaica & -1.035 & -114753.3 \\
\hline Japan & -511396.9 & $-1.87 \mathrm{E}+07$ \\
\hline Jordan & -6.947 & -64324.05 \\
\hline Kazakhstan & 414.4912 & -757668.7 \\
\hline Kenya & -2876.656 & -1851.337 \\
\hline Kiribati & & -21.483 \\
\hline Korea, Rep. & 470351.7 & -6985325 \\
\hline Kyrgyz Republic & -1812.516 & -59447.42 \\
\hline Latvia & 14.07799 & 2438.899 \\
\hline Lebanon & -1.644 & 20241.84 \\
\hline Lithuania & 633.614 & -1939.478 \\
\hline Luxembourg & -3.874 & -12196.54 \\
\hline Macao & -114.563 & -232620.9 \\
\hline Macedonia, FYR & & -2814.449 \\
\hline Madagascar & -100.87 & 13645.48 \\
\hline Malawi & -1547.534 & -519.719 \\
\hline Malaysia & 168006.9 & -3218346 \\
\hline Maldives & -0.204 & -17.472 \\
\hline Mali & -16708.06 & -401.813 \\
\hline Malta & -6.49 & 15427.83 \\
\hline Mauritania & & -4057.233 \\
\hline Mauritius & -41.942 & -7856.824 \\
\hline Mexico & 14355.18 & -882656.3 \\
\hline Moldova & & -129.825 \\
\hline Mongolia & -88.99901 & -79631.95 \\
\hline Morocco & -3581.217 & -90120.44 \\
\hline Mozambique & 907.2878 & -54323.05 \\
\hline Namibia & & -32944.64 \\
\hline Netherlands & 8853.254 & -95332.53 \\
\hline Neth. Antilles & & -744.299 \\
\hline New Caledonia & & -16420.32 \\
\hline New Zealand & 1068.089 & -259993.5 \\
\hline Nicaragua & -6850.385 & -56.987 \\
\hline Niger & & -0.65 \\
\hline Norway & -86961.77 & -284749.2 \\
\hline Oman & 98.84601 & 966823.2 \\
\hline Pakistan & -4664.338 & -399268.1 \\
\hline Panama & -1.361 & -12223.99 \\
\hline Paraguay & 13208.59 & -5084.257 \\
\hline Peru & -619.82 & -452541.2 \\
\hline Philippines & -145906.4 & -1255521 \\
\hline Poland & -162.645 & -51688.07 \\
\hline Portugal & 325.176 & -196814 \\
\hline Qatar & -0.294 & -116721.7 \\
\hline Russia & -68157.85 & -4721156 \\
\hline
\end{tabular}




\begin{tabular}{lrr}
\hline Rwanda & & -9388.952 \\
Samoa & & -40.724 \\
Saudi Arabia & -45.627 & -1535852 \\
Senegal & -2270.448 & -964.4841 \\
Seychelles & & -9.776 \\
Singapore & 32422.27 & 1646119 \\
Slovak Republic & -25346.35 & -45539.16 \\
Slovenia & -232.719 & -23492.59 \\
South Africa & -7608.69 & -1677722 \\
Spain & -20905.93 & -356613.6 \\
Sri Lanka & -2880.938 & -8688.327 \\
St. Lucia & & -61.141 \\
Sudan & -2045.467 & -2573009 \\
Sweden & -126222.8 & -634299.1 \\
Switzerland & -14387.9 & -534356.6 \\
Syria & -2143.136 & -239.541 \\
Taiwan & -220792 & $-1.86 \mathrm{E}+07$ \\
Tanzania & -25091.74 & -124946.6 \\
Thailand & -112410.9 & -3544930 \\
Togo & -20319.44 & -4353.386 \\
Trinidad\&Tobago & -0.016 & -16382.13 \\
Tunisia & -18043.63 & -10316.74 \\
Turkey & 164.9601 & -219118.3 \\
Uganda & -12388.62 & -3355.782 \\
Ukraine & -11217.65 & -170150.2 \\
UAE & 130.992 & -1754829 \\
United Kingdom & -76137.48 & -577421.4 \\
United States & -619410.6 & -8285654 \\
Uruguay & -217.0482 & -53232.03 \\
Venezuela & -5.021 & -837606.4 \\
Vietnam & 412276.4 & -65957.01 \\
Yemen & -38.59399 & -665175 \\
Zambia & -30950.12 & -171495.8 \\
Zimbabwe & 423.929 & 69641.24 \\
\hline & & \\
\hline & & \\
\hline
\end{tabular}


Figure 1. Missing imports
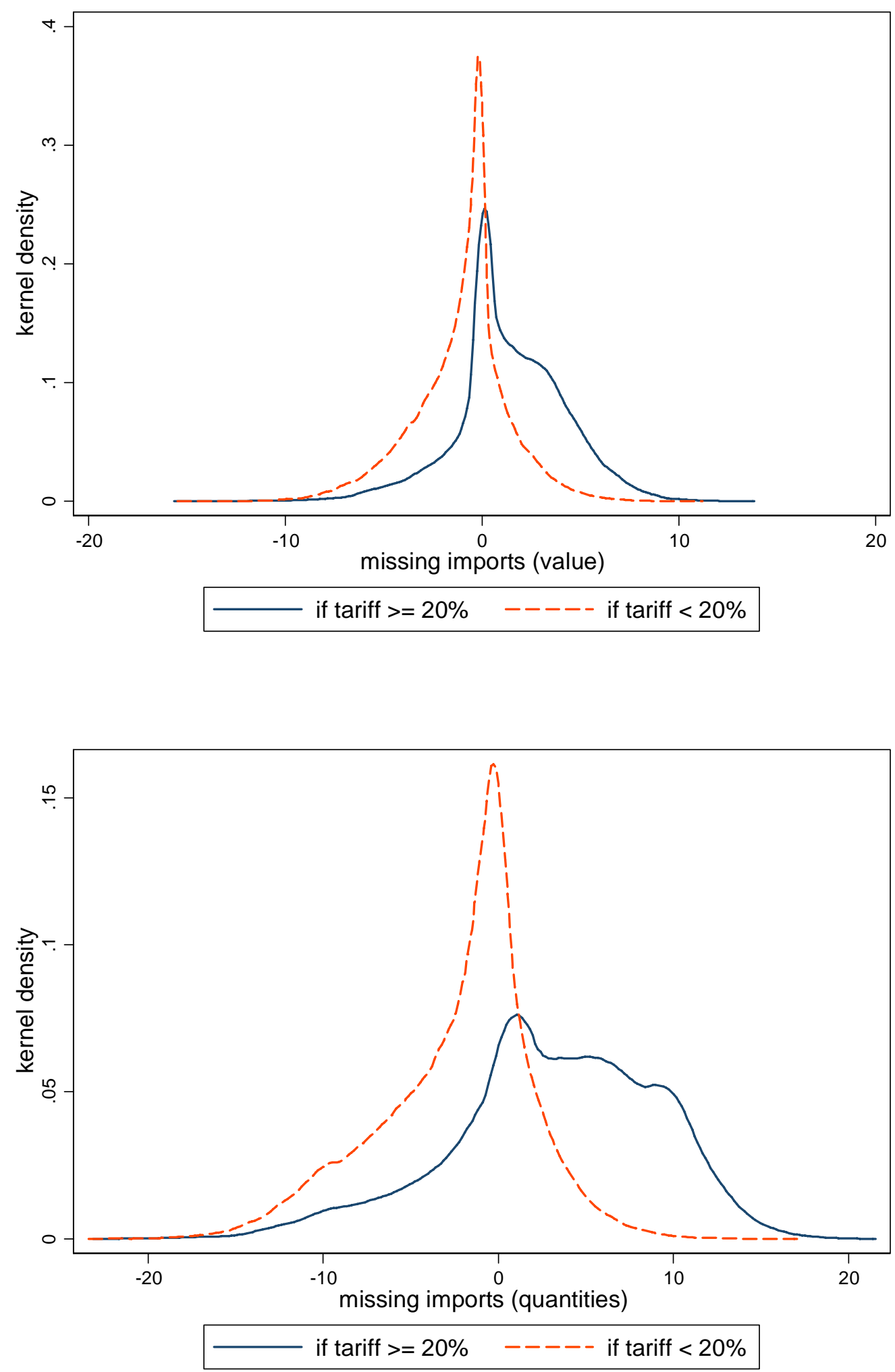
Figure 2. Tariff semi-elasticity of missing import values and ethnic Chinese migrants

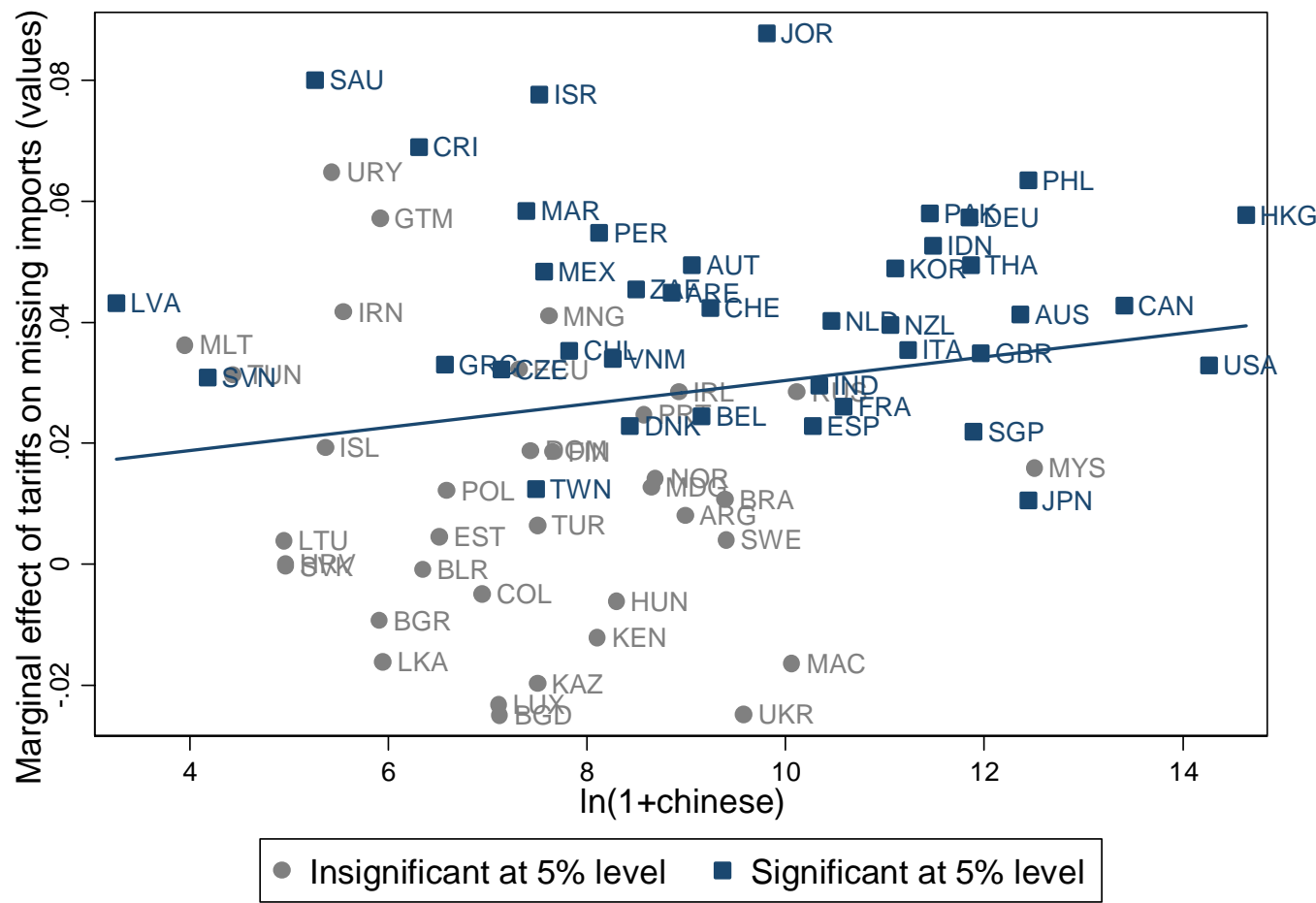

Figure 3. Tariff evasion and ethnic Chinese networks

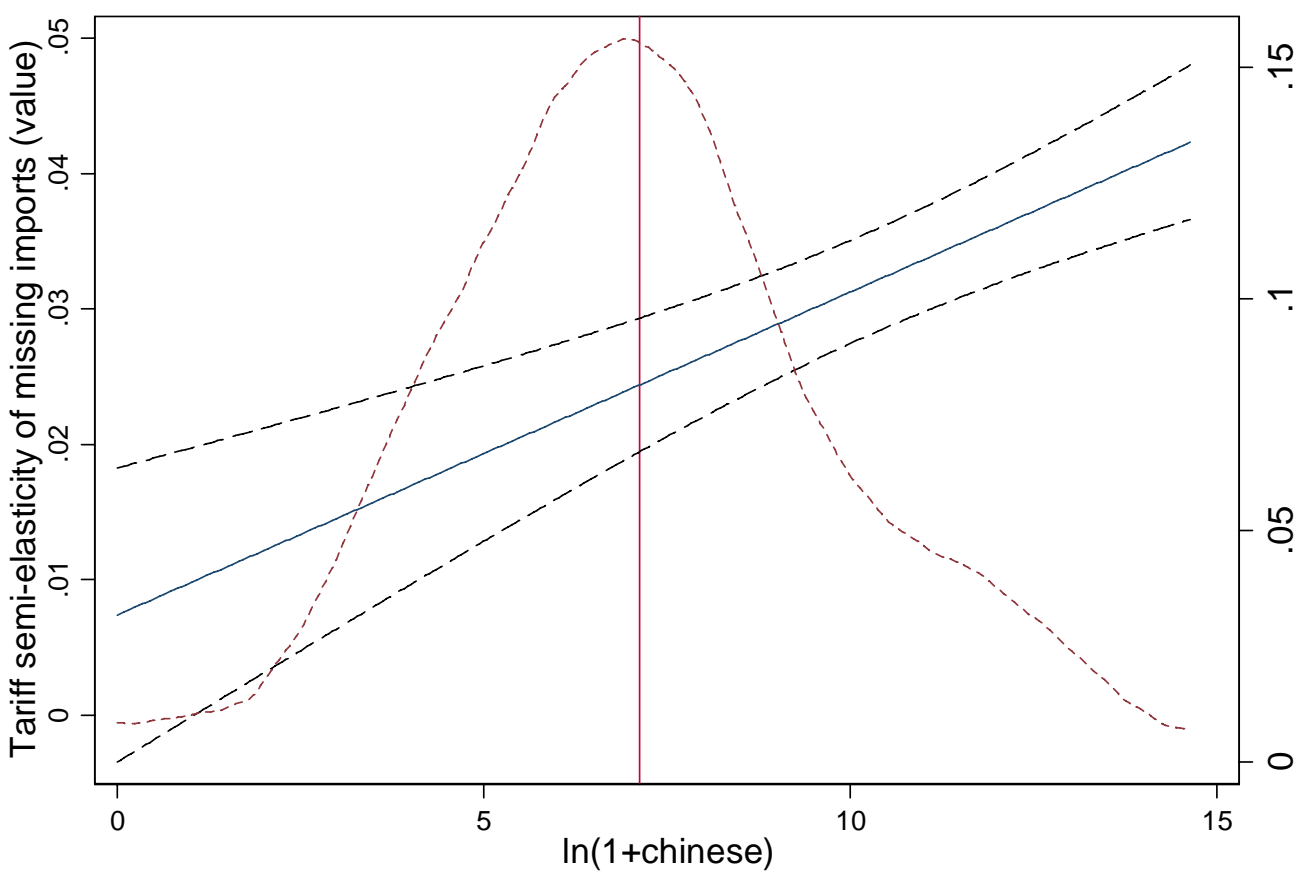

Thick dashed lines give 90\% confidence interval using product clustered s.e. Thin dashed line is a kernel density estimate of In(1+chinese). 
Figure 4. The impact of corruption and Chinese networks on tariff evasion
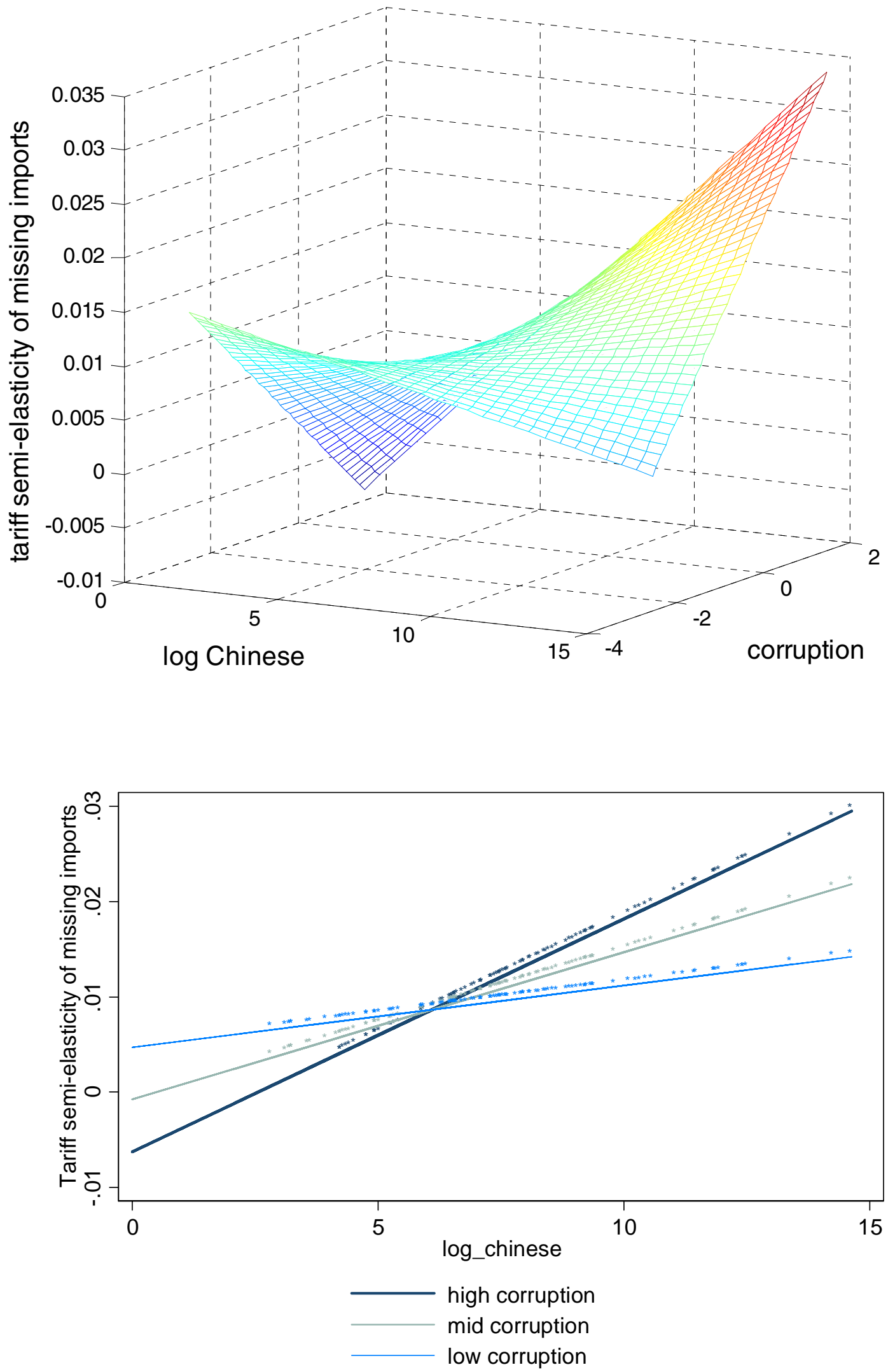

stars indicate statistical significance at the $95 \%$ level 